\title{
Impact of corporate social responsibility on the firm's financial performance
}

\author{
1.Munaza Kanwal, 2.Farida Khanam, 3.Shagufta Nasreen, 4.Shahid Hameed \\ Department of management sciences Islamia University Bahawalpur, Pakistan
}

\begin{abstract}
The concept of the corporate social responsibility of organizations has a significant interest in Pakistan over the last decade. While international data shows significant relationship between CSR and FP of the firms. This paper tries to explore the relationship between CSR \&FP by taking the data from 15 companies listed on Karachi stock exchange, using correlation analysis which is used to find the cause and effect of the relationship.

CSR is the foundation to understand the responsibilities of organization towards the society where the organization executes their activities. FP plays the vital role to carry out the CSR activities as the strong financial performance results in provision of necessary and reasonable funds and investments to carry out their social activities. These CSR activities not only enhance the firm's social value and reputation but also the profitability as well.

The study result shows that there is a considerable positive relationship between the CSR and Financial performance of the firm, and firms spending on CSR not only benefits from continuous long term sustainable development but also enjoy enhanced FP.
\end{abstract}

Key words: Corporate social responsibility, financial performance of firm, Pakistan, society welfare, Total net profit, Total asset.

\section{Introduction:}

In last few decades the concept of Corporate Social Responsibility has grown exponentially. In the $21^{\text {st }}$ century larger firms face large number of changes and challenges including the corporate social responsibility as being one of the key problems. It suggests the importance of understanding of the CSR by the organization towards the society which also impacts the financial performance of the firm.

The CSR activities are treated as an investment not as a cost or expense where it shows the relationship between corporation and the stakeholders such as the customers, investors, employees and society as a whole. The business's purpose is not only to earn profit but the welfare of the society as well. Some studies have shown the positive correlation between the CSR and financial performance while other studies show the negative relationship between them. Each company performs differently for the implementation of CSR depending on different factors like the culture of the organization, size or the stakeholder demand.

Corporate social responsibility is generally defined as while company is performing its core business operations, it considers and handles the influence of these operations on society, economy and atmosphere [10].

CSR can be defined when a firm apply its rules and regulations, the welfare of its investors and society should be considered as its duty [7].

This paper shows the impact of CSR on financial performance of the firms in 15 listed companies on Karachi Stock Exchange. Pakistan has a background of typical developing country with issues such as the low literacy rate, energy crises, lack of infrastructure, terrorism etc. The welfare role of the government is unrevealing under these conditions. Therefore, organizations have an opportunity to increase their welfare role for the society in exchange of better reputation and growth in business which ultimately leads to strong financial performance and high profitability. The society in general faces many problems in developing countries. So CSR should contribute to solve these problems and challenges.

The purpose of this study is to find out the impact of CSR on firm's financial performance, the CSR cost and economic benefits. Impact of CSR on firm's profitability (net profit \& total assets).

\section{Literature review}

CSR According to The World Business Council for Sustainable Development in its publication, "Making Good Business Sense".

Lord Holmes and Richard Watts defined CSR as "Corporate Social Responsibility is the continuing commitment by business to behave ethically and contribute to economic development while improving the quality of life of the workforce and their families as well as of the local community and society at large" 
On the other hand, the European Commission hedges its bets with two definitions wrapped into one:

"A concept whereby companies decide voluntarily to contribute to a better society and a cleaner environment, a concept whereby companies integrate social and environmental concerns in their business operations and in their interaction with their stakeholders on a voluntary basis.[6]

$\sim \sim$ Spicer (1978 A.B), Rosen et al. (1991), Graves and Wad dock (1994) and Pave \& Krausz (1996) explained that when a firm adopts the corporate social responsibility, it will be easy for the firm to generate capital because financial institutions and shareholders will attract toward a firm due to the image created by the firm's CSR [11].

Those companies which provide healthy environment to their employee will be successful in attracting new brilliant employees and enhancing commitment in current employees which results in higher performance [5].

Different firms worldwide investing huge amounts on CSR to enhance its FP through retaining the current employees, attracting new brilliant employees, attracting shareholders due to the strong image created by the firm's CSR which leads to the better FP.

Performance is generally considered in two ways end results and the means to achieve the results. Different tools are used to measure different type of performances in firms, such as steering control(SPC),ABC(Activity based costing),EVA, MVA, balanced score, ROI,EPS and results of NP and fluctuations in assets.

"Financial performance is measuring the results of a firm's policies and operations in monetary terms. These results are reflected in the firm's return on investment, return on assets, value added" [4].

A subjective measure of how well a firm can use assets from its primary mode of business and generate revenues. This term is also used as a general measure of a firm's overall financial health over a given period of time, and can be used to compare similar firms across the same industry or to compare industries or sectors in aggregation [4].

The optimistic involvement of CSR has a probability to the advancement of society and businesses. The interest on the CSR is rising due to its potential of persuading firm's performance. This study presents that ROE and ROA are used to measure the financial performance which is influenced by CSR activities. The CSR strategies and operations in market and non-market have impact on performance of business. The empirical studies contain essentially two type of study of the relationship between CSR and financial performance. The CSR have significant positive correlation with financial performance measure. There are two measure to evaluate the financial performance and CSR in which one is market measure and other one is accounting measure used by the researchers when firms engage in either socially responsible or irresponsible activities initially uses the event study methodology to evaluate the short-run financial impact. The second type of study using accounting or financial measures of profitability to examines the relationship between measures of long term financial performance, and some measure of corporate social performance [13].

Corporate social responsibility manages reputation by creating good image in the mind of customers, suppliers etc. Stakeholders will think that when a company is fulfilling its social responsibility then how it is possible that it will do anything bad for them, so their trust will enhance on company. Stakeholders trust will impact on company's profitability and success. Therefore, it is concluded that corporate social responsibility has positive impact on the financial performance of a firm [1].

One of the study concluded that CSR has a positive impact on the firm's financial performance. Those firms which do not pay attention on CSR's activities have not good financial performance as compared to those who are responsible in performing social activities. On the other hand, firm's profit can be reduced due to higher cost occur on performing social activities. Those firms which play role for the welfare of society avoid the cost arising from people's claims about their safety. When firms do not consider the influence of its operations on environment or society then it creates a bad image in the mind of customers and sales decrease. CSR's activities such as donations, activities for the welfare of its employees and society etc create a good image in the consumer's mind and protect the firm from decrease in sales. Firm performs its CSR toward lenders by paying back loans and installments as they become due and towards shareholders by giving appropriate portion of their share from firm's earning continuously. By taking such actions, lenders and investors will attract towards company and continue to contribute their money in the firm; therefore firm's financial condition will improve $[8]$.

Another study concluded that, if firm works for the welfare of its employees, suppliers, investors, and consumers etc then it will be profitable. If a company makes rules and regulation about the needs and satisfaction of its employees such as rules for safe working environment, that is the evidence of the company's social responsibilities towards them. Employee satisfaction impacts on their performance and ultimately financial performance improvisation. While making and promoting the product, company should consider all the concerns related to the product including any side effects, harms, associated dangers or even affordability in reasonable range, which will eventually drive the customers towards the product resulting from the image created by the company in context of its CSR, therefore, the financial performance will enhance. When a company is doing something for the benefits of its investors like rules about appropriate information available 
for the stockholders, their involvement in making decisions, then it represents firm's CSR for its investors. Stock price of more CSR firms will increase as compare to those who do less for the benefits of it investors [9]. Firm performs its CSR towards it employees giving them bonuses, compensation, remuneration on time, therefore they will be motivated and their commitment towards firm will enhance which in turn increase the employee performance so firm's financial performance will increase. Firm build the strong relationship with its suppliers by timely paying the purchase price of goods taken on credit, by this way it attracts various suppliers and firm can purchase less expensive material because of competition. Therefore firm's financial performance will enhance. By performing CSR activities, firm can create good image in the mind of customers, government, and the public that will enhance firm's financial performance. Therefore, it is concluded that CSR has a positive impact on the firm's financial performance [8].

Positive relationship between CSR and FP is also agreed by another research. Those firms which are playing greater role for the welfare of society, atmosphere, providing health conveniences etc these creates good reputation in the mind of customers, suppliers, employees etc in competitive setting. . These firms get more benefits than the cost they have to bear for the welfare of society. Therefore Firm's CSR enhance the financial performance of firm, so when a firm has good FP it can do more for the welfare of society. This study shows that firm's CSR and FP are related to each other. Companies should consider the CSR when any decision is made because it protects the company from expenses which occurred due to criticisms, oppositions and strikes and lawsuits against environment hazardous etc [2].

They concluded that CSR is the best mean to enhance the firm's financial performance. Therefore, it was concluded that there is positive relationship between CSR and firm's FP. [3].

This study shows that there is a significant positive correlation between CSR and financial performance linked with the series of bottom line benefit. Measure of financial performance is a simpler task but have specific complications. It is evaluate through different theoretical implications. The argument is that the firms which have strong financial performance have the ability to invest more in social responsibility that have a long term strategic impact such as offer services to community as a result it attract more investor and skilled employees.[12].

Literature from the previous researches shows that spending ones creates the positive image on the different stake holders of the firms which leads to enhance the FP

\section{CSR Campaigns}

Table1.1

Here the table1.1 shows the CSR campaign of different companies in various sectors in last five years in Pakistan

\begin{tabular}{|c|c|c|}
\hline S.NO & Companies & Campaign \\
\hline 1 & $\begin{array}{l}\text { Nestle Pakistan } \\
\text { limited }\end{array}$ & $\begin{array}{l}\text { Contribution in flood relief activities, Drivers Safety } \\
\text { Training Institute in collaboration with the National Highway and the Motorway Police, } \\
\text { Launch of Healthy Kids nutrition awareness programmed, another drinking water filtration } \\
\text { plant in Khanewal near Kabirwala factory, donation of milk and company products to } \\
\text { underprivileged schools, Continued Support for the Dairy and Rural } \\
\text { Development Foundation training program involving } 16000 \text { farmers, }\end{array}$ \\
\hline 2 & $\begin{array}{l}\text { Unilever } \\
\text { Pakistan food } \\
\text { limited }\end{array}$ & $\begin{array}{l}\text { Environmental protection measures include Distribution Centre rationalization \& cross } \\
\text { docking, Dry floor initiatives for reducing water waste in floor wash. Pakistan Poverty } \\
\text { Alleviation Funds in Purnawan, Bhai Pheru, energy conservation, contribution to national } \\
\text { exchequer, occupational safety and health. }\end{array}$ \\
\hline 3 & $\begin{array}{l}\text { National foods } \\
\text { limited }\end{array}$ & $\begin{array}{l}\text { The National Rural Support Programme (NRSP), NFL product donations, rations packs for } \\
\text { individual families, Relief goods were distributed to the people of Badin. }\end{array}$ \\
\hline 4 & $\begin{array}{l}\text { Rafhan maize } \\
\text { products } \\
\text { company } \\
\text { limited }\end{array}$ & $\begin{array}{l}\text { Provided financial assistance to Harman's SOS Children Village, sponsored an Eye Camp for } \\
1,700 \text { girls students at a high school, borne annual educational expenses of girls students at } \\
\text { college level, donated beds for ICU in a local hospital and shared treatment expenses for poor } \\
\text { patients at distinctive hospitals in the community. }\end{array}$ \\
\hline 5 & $\begin{array}{l}\text { JUBILEE } \\
\text { general } \\
\text { insurance }\end{array}$ & $\begin{array}{l}\text { JGI-sponsored home schools are functioning at Rehri Goth, Pipri, and two at Ghaggar Phatak, } \\
\text { in the province of Sindh }\end{array}$ \\
\hline 6 & $\begin{array}{l}\text { SAPPHIRE } \\
\text { TEXTILE }\end{array}$ & ance infrastructure and sindh develop \\
\hline 7 & lucky cement & $\begin{array}{l}\text { Donate to Karachi School of Business and Leadership (KSBL), Razzak Tabba Academic Block } \\
\text { at IBA. Construction Material Research Group Fellowship at NED University. The Hub School } \\
\text { Project, Concern for Children Trust Partnership. Scholarships / Educational Assistance, } \\
\text { Changing Lives Community Development, Changing Lives Health. }\end{array}$ \\
\hline 8 & $\begin{array}{l}\text { shell pak } \\
\text { limited }\end{array}$ & $\begin{array}{l}\text { In 2010, SPL structured an education endowment, working towards safer roads creating an } \\
\text { enterprise generation supply chain. Three years ago, SPL began a merit-based scholarship } \\
\text { programmed to support financially needy university students at engineering and business } \\
\text { universities in Pakistan. Shell Tameer expanded its enterprise generation activities in 2012, and } \\
\text { new Tameer Information Desks for Entrepreneurs (TIDE) were opened at three new } \\
\text { universities: IBA in Karachi, LUMS in Lahore and Bahria University in Islamabad. }\end{array}$ \\
\hline
\end{tabular}




\section{Objective of the study}

- The main purpose of this study is to find impact of CSR on financial performance of the firm.

1) To find the relationship between CSR cost and economic benefit.

2) To find the relationship between CSR \& firm's profitability (net profit \& total assets).

\section{Hypotheses:}

H1: CSR has significant impact on the firm's financial performance

H2: CSR has significant impact on firm's net profit

H3: CSR has significant impact on firm's total assets

\section{Research model:}

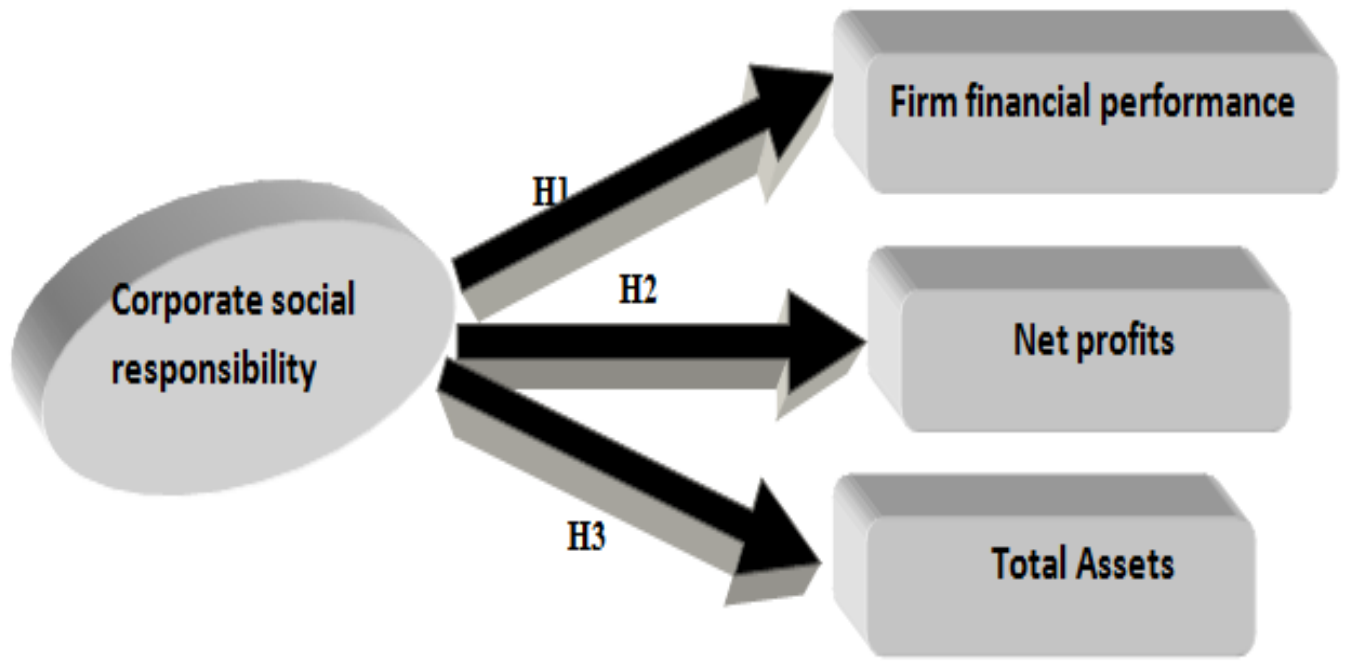

\section{Sample}

\section{Research methodology}

In this research the sample of five year data from (2008 to 2012) of 15 Pakistani listed corporations in Karachi stock exchange (shown in table 1.1) has been taken. The data which is used in this research financial data, earnings, total assets and CSR extracted from annual reports of the firms.

\section{Research Instrument}

For profitability testing we use the correlation method to find the cause and affect relationship between CSR and impact on financial performance of the firm. We collect the data, net profits, total assets and the CSR of the company's annual reports for (2008 to 2012) and then find out the relationship between them. In this report only those companies which shows the CSR in amount (RS) and also listed in Karachi stock exchange

\section{Analysis}

In this study to find the impact of CSR on the financial performance of firm the net profit, total assets and CSR of five year data(2008 to 2012) of 15 companies (shown in table 1.1) listed in KSE has been collected in rupees. 
Net profit:

Table 1.2

\begin{tabular}{|c|c|c|c|c|c|c|}
\hline & NET PROFIT & & & & & \\
\hline & & & & RS in 000 & & \\
\hline sr. \# & companies names & 2008 & 2009 & 2010 & 2011 & 2012 \\
\hline 1 & nestle pakistan Ltd & 1552894 & 3005133 & 4112849 & 4668357 & 5864511 \\
\hline 2 & atlas honda Ltd & 703009 & 224,533 & 712,458 & $1,002,556$ & $1,204,109$ \\
\hline 3 & attock cement pakistan Ltd & 435025 & $1,492,951$ & $1,016,685$ & 684,429 & $1,436,649$ \\
\hline 4 & fauji cement company Ltd & 413598 & 1007623 & 250179 & 425661 & 552590 \\
\hline 5 & unilever pakistan Ltd & 1984326 & 3055740 & 3273202 & 4094232 & 5491255 \\
\hline 6 & Jubilee general insurance company Ltd & -267249 & 656464 & 450151 & 797189 & 826576 \\
\hline 7 & National food Ltd & 156546 & 139461 & 86559 & 230597 & 583276 \\
\hline 8 & pakistan cable Ltd & 65397 & 63921 & 45506 & 85682 & 139956 \\
\hline 9 & pakistan refinery Ltd & 2110744 & -4571655 & -2975215 & 223956 & -1615717 \\
\hline 10 & Rafhan maize products company Ltd & 1492365 & 1297080 & 1837937 & 4116445 & 5183660 \\
\hline 11 & tata textile mills Ltd & -224651 & -234551 & 440600 & 303465 & 41375 \\
\hline 12 & sapphire textile mills Ltd & 617,730 & 179,842 & $1,015,544$ & 1607405 & $1,073,679$ \\
\hline 13 & nishat textile mills Ltd & $5,857,587$ & $1,268,001$ & $2,915,461$ & $4,843,912$ & $3,528,567$ \\
\hline 14 & lucky cement company Ltd & $2,677,670$ & $4,596,549$ & $3,137,457$ & $3,970,400$ & $6,782,416$ \\
\hline 15 & shell pakistan Ltd & 2326948 & $2,562,948$ & $1,615,582$ & 905,990 & $-2,082,531$ \\
\hline
\end{tabular}

In table 1.2 that was the net profit of last five years in rupee of 15 listed companies in Karachi stock exchange

Table 1.3

Total assets:

\begin{tabular}{|c|c|c|c|c|c|c|}
\hline & Total assets & & & & & \\
\hline & & & & RS in 000 & & \\
\hline sr. \# & Companies names & 2008 & 2009 & 2010 & 2011 & 2012 \\
\hline 1 & nestle pakistan Ltd & 16684176 & 18586980 & 8352923 & 35179859 & 50872717 \\
\hline 2 & atlas honda Ltd & 8704651 & $7,485,064$ & $8,522,276$ & $9,621,230$ & $10,960,417$ \\
\hline 3 & attock cement pakistan Ltd & 5870947 & $6,972,801$ & $7,058,909$ & $7,743,149$ & $8,901,483$ \\
\hline 4 & fauji cement company Ltd & 12454493 & 21446501 & 26779999 & 32210829 & 30703465 \\
\hline 5 & unilever pakistan Ltd & 11386 & 11425715 & 13501107 & 15976302 & 18371016 \\
\hline 6 & Jubilee general insurance company Ltd & 5425172 & 6419889 & 7671596 & 8974835 & 10759381 \\
\hline 7 & national food Ltd & 1746655 & 1911776 & 2674360 & 2854741 & 3159769 \\
\hline 8 & pakistan cable Ltd & 3345900 & 3007734 & 3640949 & 3807776 & 3679157 \\
\hline 9 & pakistan refinery Ltd & 23772076 & 32566845 & 30859715 & 24978767 & 34211198 \\
\hline 10 & Rafhan maize products company Ltd & 3099295 & 2473347 & 4015673 & 2033828 & 2039930 \\
\hline 11 & tata textile mills Ltd & 4142217 & 3783111 & 3639512 & 4999432 & 3781960 \\
\hline 12 & sapphire textile mills Ltd & 12324265.1 & $10,189,525$ & 11579966.3 & $14,393,190$ & $14,056,507$ \\
\hline 13 & nishat textile mills Ltd & $40,277,289$ & $31,512,686$ & $46,182,314$ & $54,088,904$ & $56,626,383$ \\
\hline 14 & lucky cement company Ltd & $34,239,074$ & $38,392,362$ & $38,310,244$ & $41,209,855$ & $40,631,241$ \\
\hline 15 & shell pakistan Ltd & 32653733 & $33,653,733$ & $38,497,511$ & $49,159,081$ & $44,895,862$ \\
\hline
\end{tabular}

In table 1.3 data of assets of last five years taking from annual reports of the firms 
Corporate social responsibility:

Table 1.4

\begin{tabular}{|c|c|c|c|c|c|c|}
\hline & CSR & & & Rsin 000 & & \\
\hline s.no & compnies & 2008 & 2009 & 2010 & 2011 & 2012 \\
\hline 1 & nestle pakistan Ltd & 58529 & 80177 & 87196 & 62736 & 73756 \\
\hline 2 & atlas honda Ltd & 8080 & 10042 & 3590 & 10898 & 14205 \\
\hline 3 & attock cement pakistan Ltd & 204 & 6856 & 8914 & 3997 & 5595 \\
\hline 4 & fauji cement company Ltd & 0 & 5206 & 1880 & 17678 & 2300 \\
\hline 5 & unilever pakistan Ltd & 30498 & 30215 & 33780 & 34273 & 9121 \\
\hline 6 & Jubilee general insurance company Ltd & 5017 & 1733 & 2920 & 6850 & 8089 \\
\hline 7 & national food Ltd & 186 & 783 & 3000 & 2528 & 8584 \\
\hline 8 & pakistan cable Ltd & 1020 & 1500 & 150 & 2010 & 3200 \\
\hline 9 & pakistan refinery Ltd & 8110 & 3127 & 420 & 1237 & 620 \\
\hline 10 & Rafhan maize products company Ltd & 0 & 1500 & 1500 & 2500 & 2390 \\
\hline 11 & tata textile mills Ltd & 2725 & 2824 & 2400 & 2835 & 3873 \\
\hline 12 & sapphire textile mills Ltd & 5479 & 2637.5 & 21069 & 38517.1 & 16600.4 \\
\hline 13 & nishat textile mills Ltd & 2665 & 2774 & 724 & 2857897 & 3097102 \\
\hline 14 & I ucky cement company Ltd & 6872 & 5764 & 104046 & 89822 & 184507 \\
\hline 15 & shell pakistan Ltd & 28045 & 27055 & 30695 & 22337 & 13410 \\
\hline
\end{tabular}

In table 1.4 that was the spending of firms during last five years

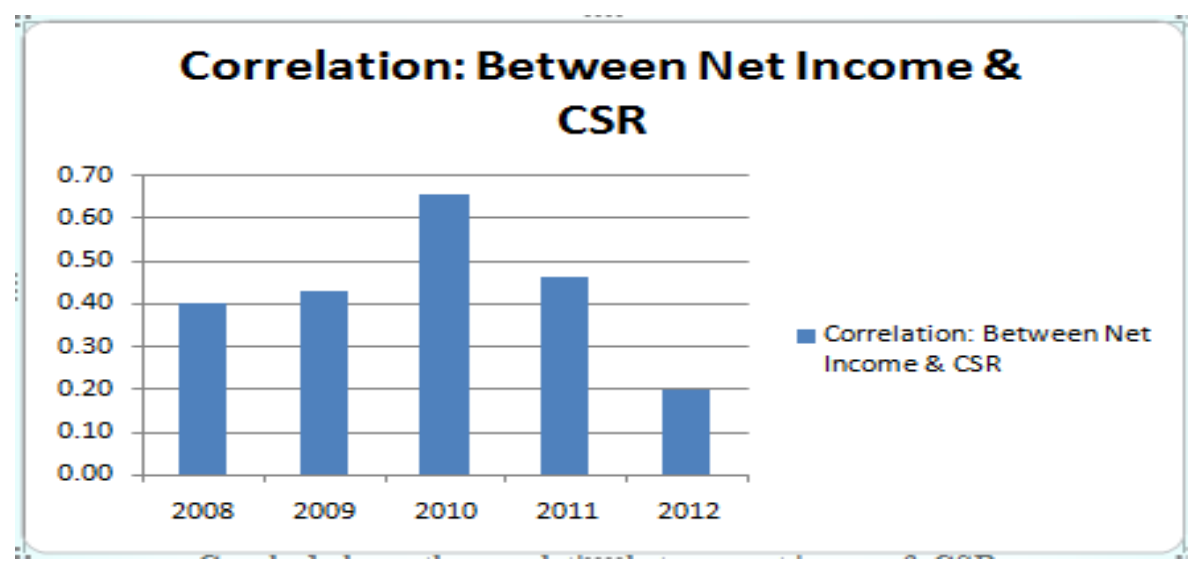

Graph: 1 shows the correlation between net income \& CSR.

\section{Interpretation:}

The correlation between the CSR and net income is moderate week in year 2008 and 2009 as shown in graph 1 . But in 2010 and 2011 the graph show a strong positive correlation between the CSR and net income while in 2012 the correlation is week between them as shown in graph.1.

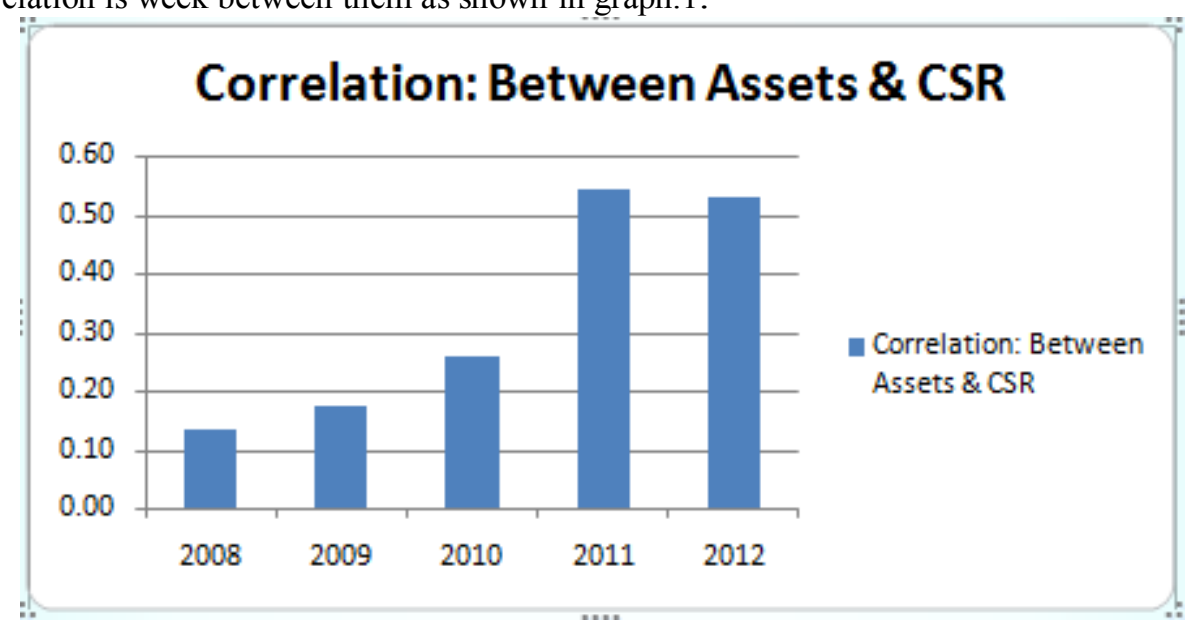

Graph: 2 show the correlation between the assets \& CSR. 


\section{Interpretation:}

There is a week correlation exist between the total asset and CSR in 2008, 2009 \& 2010 as shown in graph 2 due to the political and economic condition in Pakistan. But in 2011 and 2012 the correlation is very strong between the asset and CSR (graph.2) due to the highly favorable condition in Pakistan.

\section{Correlations:}

(Correlation b/w net income \& asset with CSR)

The table shows the positive correlation between CSR \& net income of the companies and CSR \& total assets of five year data of $15 \mathrm{KSE}$ listed companies.

Table 1.5

\begin{tabular}{|l|l|l|}
\hline Years & \multicolumn{1}{|c|}{ Net income \& CSR } & Assets \&CSR \\
\hline 2008 & 0.40 & 0.13 \\
\hline 2009 & 0.43 & 0.17 \\
\hline 2010 & 0.66 & 0.26 \\
\hline 2011 & 0.46 & 0.54 \\
\hline 2012 & 0.20 & 0.53 \\
\hline
\end{tabular}

\section{Results \& discussion:}

As the tables given above 1.2 to 1.4 these are the net profits, changing in assets and spending s on CSR different sectors in Pakistan during 2008 to 2012. Tables 1.5 showing the positive relationship between CSR and FP. Five years Data has been collected from 15 companies listed at Karachi stock exchange. Correlation is used to measure the cause and effect relationship between CSR and FP. In first measure, corporate social responsibility is compared with net profit of the company which shows positive relationship between CSR and net profit. In Second measure CSR is compared with total assets of the firm which also shows the positive link between CSR and total assets. Thus By these findings, the results show that there is significant positive relationship between CSR and FP. Results show that as the company increased spending on CSR the financial performance of the firm enhanced.

\section{Conclusion}

A propos relationship between the CSR and FP in the present study tried to provide the returning answer of the main question, Is there any relationship between CSR and FP and if there is any relationship between them, then what is the nature of the relationship? So the results shows that there is positive relationship between CSR and firms FP, this positive relation on the basis of Pakistan's firms data showing the positive social corporate behavior of Pakistani firms towards society. The result of hypothesis indicates that CSR has positive impact with each variable of firm's financial performance. All three hypothesis used in this study are accepted. From $\mathbf{H 1}$ it is concluded that significant positive relationship exists between CSR and firm's financial performance. $\mathbf{H 2} \& \mathbf{H 3}$ is also accepted as significant positive impact is found between CSR and net profit or total assets. Pakistani firms aware and spending more for society well being, environmental protection, and health and education facilities. Also spending on employees well being to retain and attract of new competent employees and for building confidence. Overall these all spending not just for the incessant and long term development also for the economic benefit of firm.

\section{Recommendation and suggestions}

- This study indicates CSR is now considered as an investment not as expenditure therefore companies should invest in performing CSR because if firms do so they will get more financial benefits than what invested in CSR.

- In addition, companies should not only invest on CSR but also disclose its spending on CSR to all stakeholders that how, where and what amount they have invested in CSR. Companies invest a lot of money on advertisement to create a good image in the mind of customers but if they also invest a little portion of this amount on CSR can also build good image.

- Corporate social responsibility manages reputation by creating good image in the mind of customers, suppliers etc. Stakeholders will think that when a company is fulfilling its social responsibility then how it is possible that it will do anything bad for them, so their trust will enhance on company. Stakeholders trust will impact on company's profitability and success. Therefore, it was concluded that corporate social responsibility has positive impact on the financial performance of a firm.

- As with the passage of time competition between the firms is increasing and stakeholders can easily switch from one firm to another therefore firms should do more and more to attract stakeholders so that companies financial performance increase. Therefore, firms should spend on performing socially responsible activities 
and by this companies will protects itself from complaints, objections, and lawsuits which occur because of destroying atmosphere and injuring employees due to hazardous operations of companies.

\section{References:}

[1] Brine, M., Brown, R., \& Hackett, G. (n.d.). Corporate social responsibility and financial performance in the Australian context. 4758.

[2] Ehsan, S., Kaleem, A., \& Jabeen, S. (2012). Exploring the interaction between Financial Performance and Corporate Social Responsibility in Pakistani Firms. J. Basic. Appl. Sci. , vol 2(10), 10431-10439.

[3] Flammer, C. (2012). Does corporate social responsibility lead to superior financial performance? A regression discontinuty approach. 1-35.

[4] Farlex Inc (2012), Defination of financial performance, [Online] Available: http://financialdictionary.thefreedictionary.com/Financial+Performance (july 24,2013).

[5] Globescan Inc (2005), Definition of corporate social responsibility survey, [Online] Available: http://www.globescan.com/rf_csr_first_01.htm.( February 3,2007).

[6] Hopkins, M. (2011), Definition of Corporate Social Responsibility, http://mhcinternational.com/articles/definition-of-csr (june 23,2013)

[7] Khanifar, H., Nazari, K., Emami, M., \& Soltani, H. A. (2012). Impacts corporate social responsibility activities on company financial performance. interdisciplinary journal of contemporary research in bussiness , VOL 3, NO 9, 583-592.

[8] LINH, N. T., \& HIEU, P. D. (2011). Impacts of Coprate Social Responsibility On The Financial Performance of The Firms. 1 -38.

[9] Mishra, S., \& Suar, D. (2010). Does Corporate Social Responsibility Influence Firm Performance of Indian Companies. Journal of Business Ethics, 571-601.

[10] PJC, (2006), "Parliamentary Joint Committee on Corporations and Financial Services 2006, Corporate responsibility: Managing risk and creating value", Canberra.

[11] Spicer, B. H. (1978), "Investors, corporate social performance and information disclosure: An empirical study", Accounting Review 53, 94-110.

[12] Tsoutsoura, M. (2004). Corporate Social Responsibility and Financial Performance. Applied Financial Project , 1-21..

[13] Uadiale, O. M., \& Fagbemi, T. O. (2012). Corporate Social Responsibility and Financial Performance in Developing Economies: The Nigerian Experience. Journal of Economics and Sustainable Development , Vol.3, No.4, , 44-55. 